\title{
Screendance: Learning, Teaching, Living
}

Harmony Bench, The Ohio State University with

Jason Bahling, Ben Estabrook, Natalie Gotter, Eric Nordstrom, and Ellen Maynard

Keywords: academia, teaching, training, screendance, U.S.

Prompted by recent conversations in the field regarding screendance pedagogy, I was interested to hear from current and former students on the topic of academic and professional training. I asked Ellen Bromberg (University of Utah), Mitchell Rose (The Ohio State University), and Douglas Rosenberg (University of Wisconsin, Madison), all of whom lead screendance certificate programs or focus areas in American universities, for recommendations. I would like to thank Jason, Ben, Natalie, Eric, and Ellen for taking the time to speak with me. What follows is an edited version of our conversation. In line with best practices, all contributors had an opportunity to review their comments prior to publication.

- Harmony Bench, April 2016

\section{Harmony Bench: To begin, could you each just say a few words about your background and how you first encountered screendance?}

Jason Bahling: I kind of fell into screendance, which I think is a common thread among screendance makers. I went to the University of Wisconsin-Madison thinking I was going to do video installation art. But the Inter-Arts and Technology program is housed in the Dance department. That was a bit of a bizarre jump for me at the time, but it was a great way of framing art practice and learning how to communicate nonverbally. We all called it the Doug Rosenberg School of Art.

Ben Estabrook: I had aspirations of going to the Film program at UCLA, but when I got there, I stumbled onto the World Arts and Cultures department because I was interested in documentary film and folklore. David Gere and Vic Marks had a pretty profound impact on me and presented me with the first examples of screendance that I had ever seen. At the time of my studies, John Bishop taught film production, and Judy Mitoma was finishing up her Envisioning Dance book. I made my first dance film in 1999. I later went to graduate school at the University of Utah and got an MFA in Film, and also did the Screendance Certificate with Ellen Bromberg. 
Natalie Gotter: I was interested in screendance because I have a media and advertising background, and screendance seemed like a natural thing to incorporate into my Modern Dance studies. I'm currently half-way through the Screendance Certificate Program at the University of Utah and in my second year of graduate school for dance.

Ellen Maynard: I had some early experiences with screendance in high school working with someone on a senior thesis. I ended up sitting in the editing suite with the film editor to help him edit because he didn't understand what was important in the dance. When I went to the Dance department at The Ohio State University, I was able to work with lots of different people: I was very inspired by Lily Skove who taught dance documentation and Norah Zuniga Shaw who encouraged us to reflect on what it means to use projection. Mitchell Rose comes to filmmaking with more of a concern for the audience. I also got a Video Art minor and worked with Dan Shellenberger, who loved the possibilities of art and of living artfully, and his inspiration was contagious.

Eric Nordstrom: I didn't do screen work until I started my MFA at The Ohio State University. I was focused much more on contact improvisation, which is my movement practice. But at OSU, I worked a lot with Mitchell Rose, who placed a lot of emphasis on the technical aspects of filmmaking and editing. My final thesis project was a dancefilm.

Harmony: Each of you came to screendance differently, and you represent different career stages and different schools of thought. Reflecting on your training, what are some main ideas that inform your work and process, and, perhaps, your own teaching?

Natalie: At the University of Utah, there is an immense sense of freedom in what work we produce, which is very beneficial because everyone in the program has a completely different point of view. Independence and maturity are expected of everyone getting the Certificate. Ellen Bromberg is so passionate about screendance, and is always willing to talk about it and anything I'm creating I know I can always bring to her and ask for her opinion about it. Doug Rosenberg was a distinguished speaker for the Utah Screendance Festival this past fall, and one of the things he said that stood out to me is that we need to find a new way to talk about screendance. It's not just film, and it's not just dance. But that raises a question for me about how we're teaching it, and how we develop that language in screendance curricula.

Jason: I took about five video courses at the University of Wisconsin-Madison. In all of them, the teachers wouldn't sit us down and say, "These are the buttons and how they work." Software programs were changing so fast, it just became clear in the late 1990s or early 2000s that students were going to learn programs faster than you could teach them-so the video courses focused on content. We focused on how you tell stories and how you make creative choices that are more profound and poetic than pixelating 
or a kaleidoscope effect. The question at the core of the teaching was how theory and practice work together. For example in creating a piece, we would constantly come back to the question of "what is this really saying?" on multiple levels: within your own practice, your geographic context and network, and then within art history as a whole.

Ben: I've been fortunate to work with Ellen Bromberg and take workshops with Katrina McPherson and Thierry De Mey, and they all have pretty radically different approaches to exploring the medium of film, and how to bring dance into that. Because I had a background in performance documentation, it was initially really hard for me to not have continuity of the choreography-it took a lot of effort to override my instincts. So it's important to me to expose students to the range of what you can do-that when you're filming, you're gathering these textures that you'll take into the edit to create something entirely new, and to really think about how you're choreographing the dance through editing. There's something so liberating about that. I feel like one of the things I say way too often is that when you're shooting dance, to make sure you have an intention behind the camera. My own workshops focus more on shooting than editing, and I feel like intention is really a hard thing for a filmmaker just starting out-there needs to be thought behind every decision: where are you placing the camera, what is the framing, how are you moving the camera. Sometimes you'll see the camera moving just for the sake of moving. So I like to explore what motivates the camera movement.

\section{Harmony: Are there specific exercises that you have encountered in courses or workshops that have impacted you?}

Ellen: With Lily Skove, we watched Hilary Harris's film "9 Variations on a Dance Theme," and then we tried to do the same thing. That showed me the angle of filming changes the movement. That's a pretty basic statement, but it leads to a lot of possibilities. Lily encouraged us to just try everything out-what can you change about the space? what can you change about the lighting? When teaching us editing, Mitchell Rose would bring these really long strips of paper that represented the film in FinalCut into the computer lab, and he would show us in paper form what a splice was, what a slide was-he would show the techniques of the computer physically, and that was helpful because as dancers we related to a tangible representation of the computer technique.

Ben: Katrina McPherson has a great workshop exercise she does. She'll get the participants in a circle, two will go to the center and start to improvise and a third person will have the camera and will improvise with them. There will be a clear sense of where a shot begins and ends. In reviewing the footage afterward, it's pretty apparent where a shot gets interesting and where we lose interest. So that's a really effective way to get people to think about the beginning and ending of a shot, and thinking about editing while they are shooting. 
Eric: One of the exercises I continue to use in teaching I learned from Mitchell Rose, and the idea is to film a very short movement phrase-maybe 5 seconds-from 12 different camera angles: bird's eye, high-front, side, back, mid-front, side, back, lowfront, side, back, close-up, etc. It's a really useful exercise because it emphasizes how filming the same dance or movement phrase can be dramatically different depending on how you film it. So I use this exercise in my performance class, and I just have students use their cell phone cameras. It helps them as dancers to consider when they are performing, how is the audience seeing this—is it a high shot, a wide shot-how are you being seen?

\section{Harmony: One of the things we see all the time in screendance is the importance of collaboration. Do you have thoughts about how screendance courses and workshops either teach or don't teach students how to collaborate or how to work with a team? Or do you have experiences working collaboratively that you'd like to share?}

Natalie: One of the greatest strengths of the University of Utah is the emphasis on collaboration. That said, everyone is encouraged to be an individual artist, and there's not a lot of real-world training in collaborative relationships that one might encounter outside of academia. Even in the Screendance Certificate, with all of the coursework, you're doing everything totally by yourself: choreographing, directing, shooting, editing, sound editing. We have classmates assisting, but they are in the same boat that you are in, learning everything at once. In being introduced to what all the different options are as a screendance artist, maybe you figure out what role you are most drawn to. In the process you develop an individual artistic voice, but the realworld collaboration skills and expectations are not part of the training. Screendance feels like such a small world, and I wonder if the way it's taught lends itself to being or remaining a small world, which can be both a good thing and a bad thing, because it keeps it much more of an art form instead of something overly commercial. But at the same time, there are benefits to becoming more popular as well.

Ellen: At OSU, we didn't really touch on what it's like to create a film with high production values. The idea that you would have a gaffer or a grip or a lighting person on your dancefilm set-not there. We learned how to do all these roles on our own at a rudimentary level. It is good to have learned the DIY way, because now I can do it myself, but I think it capped my own imagination to what I can accomplish alone. I think it's easy to think that as a director of a dancefilm you play every role-and you get your friend to dance in it. But if you think about One Flat Thing, Reproduced, or Pina, or Co(te)lette-they all have huge film crews. I still think you can make a great film with your iPhone, but I think it's important to know the range of possibilities so that you're not only thinking on a small level from the get-go. As l've been working in more professional production environments, I've been learning about what it means to 
work as part of a crew and what is expected of everyone. They take everything very seriously, and so I have started to take myself and my art more seriously.

Ben: The more I study screendance, the more I think it's important to have a really good collaboration - to have someone who's deeply knowledgeable about film and someone who's deeply knowledgeable about dance. There are elements of film and dance that are really just opposed to each other; film involves a lot of hurry up and wait, so there needs to be mutual understanding to make an effective collaboration. For example, choreographers who aren't familiar with film may not be aware of just how slow it can be, and they might expect to just go, go, go-let's just change this shot. For the filmmaker, that might mean they have to move the dolly and rearrange the lights because now the dancers are in a totally different place. So the filmmaker needs to have some basic knowledge of the needs of dancers, and the dancers and choreographer need to know some basic things about film production and also the way the camera sees. I've worked with a lot of choreographers, and some have a really great intuition of what will work well on film, and those are the ones that I really enjoy working with, and who respect what I do. Others really just want a glorified performance documentation to show their stage piece. So collaboration can be challenging, because you have essentially two directors trying to meld their visions.

\section{Harmony: If you think about the work you've done and what you've learned since graduating, what are some things you wish had been incorporated into your training more?}

Jason: I think it could have been useful to understand how to do business more, especially for freelance artists. Unfortunately, business was something that was always presented like it would taint your artistic work. Outside the academic world, it's really hard to get grants, and individual grants are almost non-existent. So I think learning how to do funding could have been taught more. Even just interacting with people on a business level-I learned how to collaborate quite well, but that give-and-take is really not what happens when you're trying to sell your services. It took me moving to New York City to really understand business, because it's part of the culture here. Everybody's trying to figure out how to make $\$ 1200$ a month for rent alone.

Eric: I wish there had been more emphasis on logistics, like what is the dynamic of working with a client? Do you go in with an idea of your own and then you do it, or do you listen to them and follow their idea? How much do you bring to the table, and how much does the client bring, and what is that negotiation? What are all the things that are indirectly related to what you're doing that are nevertheless logistically necessary? And then what do you charge? What are you worth? I wonder if a way to get some of that information or experience is to have internships or collaborations in the community, where you still have guidance from a professor to help work through some of those negotiations. Making dancefilm trains you in many skills, and while your 
own objective might be to work as a dance or film artist, that work will likely be supported by applying these same skills toward marketing, promotional, or documentary ends.

\section{Harmony: What are your hopes for the future of screendance?}

Ben: It's exciting that more programs and workshops for screendance are beginning to crop up. My hope is that we'll begin to see that people aren't reinventing the wheel, just doing stuff that Maya Deren did eons ago. If people get down their history of screendance, see what's been done and see what's possible, and begin to really push dance on film - that's what I'm really excited about. I've worked with the San Francisco Dance Film Festival for a long time, and when you program a festival, it's amazing how you see so many of the same things again and again. I think many of us would agree that we've adequately explored dance in old, run-down warehouses! We can move on, there are other cool spaces. Two things that are really easy to goof up, or to just not think about, are location and costuming. But, production values have gotten so high. Films look gorgeous in the ways they are shot and lit, so that's really exciting, and I think maybe we can get into meatier stuff now. What does a dance film leave you with to chew on at the end? And what about the dancing and choreography is compelling? This is screendance, so we want to see really strong dancing-and more types of dance, not just modern. It would be really great to see some other forms of dance on film too.

Jason: I wish there was more of a sense of permanence. There's so much throw-away culture and we're swamped with information, so how do things become profound now? I'm hoping screendance will become more mature as its own art form, and I think that's happening with the International Journal of Screendance, and books by Doug Rosenberg and Katrina McPherson, and other journals and articles. I think that slowly there's more maturing of this field. It's been so wide-open for so long; it's sort of disconcerting to be like, "wow, how did this get in to this festival?" which has been my thought sometimes. There are certainly things that seem fresh to a curator or audience, and I think, well, this was done in 1966. Maybe that can't be escaped. But I think that maturity comes from pieces having both a high level of craft and recognizing the history of what has been part of the form. 


\section{Biographies}

Harmony Bench is Assistant Professor in the Department of Dance at The Ohio State University where she teaches in the areas of Dance, Media/Digital Humanities, and Performance Studies. Her writing can be found in Dance Research Journal, The International Journal of Performance Arts and Digital Media, Participations, and The International Journal of Screendance, for which she serves as co-editor with Simon Ellis.

\section{Email: bench.9@osu.edu}

Website: http://www.harmonybench.com/

Jason Bahling is a NYC based videographer, colorist, and time based artist. His videos have shown internationally in galleries, film festivals, and performances. While he actively participates in post-production for broadcast, advertising, documentary and narrative films, Jason primarily enjoys collaborating with choreographers, musicians, and theatre companies. Recent projects include: "Here Now with Sally Gross" and "Circling" with Douglas Rosenberg; "Daughter" with Li Chiao-Ping; and "4 Chambers" an immersive dance piece created with Jody Oberfelder. Jason is a founding partner of The Notion Collective, a multidisciplinary art collective that creates web art, performance art, video art, and installations.

Email: jason.bahling@gmail.com

Website: http://www.jasonbahling.com/

A native of the San Francisco Bay Area, Ben Estabrook specializes in capturing dance on camera. His interest in screendance led him to the University of Utah, where he graduated with an MFA in Film \& Media Arts and a Graduate Certificate in Screendance in 2014. He helped to found the San Francisco Dance Film Festival, for which he is the Technical Director, resident workshop instructor, and a programming committee member. He has given guest lectures on screendance at Stanford University, Mills College, and Brigham Young University.

Email: ben@sfdancefilmfest.org

Website: http://www.sfdancefilmfest.org

Natalie Gotter is a choreographer, instructor, dance performer, and filmmaker currently located in Salt Lake City. She is currently a Modern Dance MFA candidate and Screendance certificate candidate at the University of Utah. Her research focuses on the socially constructed female body and how dance and film can subvert that construction. Her work has been presented in New Orleans, Chicago, Minneapolis and, most recently, Salt Lake City.

Email: negotter@gmail.com 
Eric Nordstrom is a dance performer, choreographer, filmmaker, and teacher living in Portland, OR. He has taught at The Ohio State University, Kenyon College, the University of Oregon, Portland State University, Conduit Dance, and the Seattle Festival of Dance Improvisation. He has provided video production for Portland Opera, Tere Mathern Dance, and Portland Taiko. He studied with filmmaker Mitchell Rose and choreographer Bebe Miller at The Ohio State University, where he earned his MFA in Dance.

Email: dance.eric@gmail.com

Website: https://ppav.me

Ellen Maynard is a Brooklyn-based artist, and a graduate of The Ohio State University Department of Dance. Ellen is co-creator of The Fleet Video Dance Production, a company that documents dance performance throughout New York and creates promos and reels for dance. Ellen's dance films have placed in festivals including the International 60 Seconds Dance Film Festival, the 9th International Screendance Festival, the Third Coast Dance Film Festival, Body In Focus Video Dance Festival of Portugal, and Triskelion Arts Dance Film Lab. Ellen spends her summers as a resident videographer of Bates Dance Festival.

Email: emaynard116@gmail.com

Website: http://www.thefleetNYC.com 